\begin{tabular}{l|c|c}
\hline ISSN: 0001-5113 & ACTA ADRIAT., & SHORT COMMUNICATION \\
AADRAY & $59(2): 237-243,2018$ & \\
\hline \hline
\end{tabular}

DOI:10.32582/aa.59.2.10.

\title{
On the recent occurrences of shortfin mako shark, Isurus oxyrinchus (Rafinesque, 1810) in the Adriatic Sea
}

\author{
David UDOVIČIĆ ${ }^{1}$, Pero UGARKOVIĆ ${ }^{2}$, Frane MADIRACA ${ }^{3}$ \\ and Branko DRAGIČEVIĆ ${ }^{*}$ \\ ${ }^{1}$ Institute of Oceanography and Fisheries, Šetalište Ivana Meštrovića 63, 21000 Split, Croatia \\ ${ }^{2}$ Velebitska 24, 21000 Split, Croatia \\ 3"Sharklab ADRIA", Malta \\ *Corresponding author, e-mail: brankod@izor.hr
}

Eight individuals of the shortfin mako shark, Isurus oxyrinchus (Rafinesque, 1810) have been recorded in the period from 2014 to 2017 in the Adriatic Sea. The specimens presented in the paper were identified on the basis of photographic evidence. Occurrences of juvenile specimens suggests that Adriatic Sea could serve as a nursery area for this species, especially its eastern part. A review of the previously documented occurrences of this species in the Adriatic Sea is given in this article.

Key words: Lamnidae, Mediterranean Sea, shortfin mako, migratory species

\section{INTRODUCTION}

Shortfin mako shark, Isurus oxyrinchus (Rafinesque, 1810) is a cosmopolitan epipelagic species present in temperate and tropical waters of all oceans including the Mediterranean Sea (LAST \& STEVENS, 1994, YAMADA et al., 1995). It can be found from surface down to $750 \mathrm{~m}$ (WEIGMANN, 2016), usually from 100 to $150 \mathrm{~m}$ (BIANCHI et al., 1999) mostly occurring where sea temperatures are higher than $16^{\circ} \mathrm{C}$ (COMPAGNO, 2002). In the area of northwest Atlantic, this species shows preference for warmer waters, in the range $22-27^{\circ} \mathrm{C}$ (VAUDO et al., 2016). Adults feed mostly on bony fishes (COMPAGNO et al. 1989.), but also on crustaceans, cephalopods and, in lesser amount, other elasmobranchs (MAIA et al., 2006). Larger individuals may feed on larger prey such as billfish (LAST \& STEVENS, 1994) and small cetaceans (WHITE et.al., 2006). There is a large difference in size at sexual maturity between the sexes. In the northwest Atlantic, males reach maturity at about $195 \mathrm{~cm}$ and females at about 265-280 cm (PRATT \& CASEY 1983, STEVENS 1983, CLIFF et al. 1990).

According to IUCN (CAILLIET et.al., 2009) this species is showing significant declines in abundance in the Mediterranean Sea caused primarily by fishing pressure and inadequate management wherefore IUCN has listed them globally as Vulnerable (VU) and Critically Endangered (CR) for the Mediterranean Sea.

This species is also present in the Adriatic Sea where majority of its occurrences have been reported in the $19^{\text {th }}$ century. BRUSINA (1888) reported on 35 occurrences of this species for the 
period 1872-1888. Notable decline occurred in the $20^{\text {th }}$ century when only 5 specimens were recorded in the Adriatic Sea (SOLDO \& DULČIĆ, 2003). Last documented record of this species from the eastern Adriatic Sea dates back to 1972 when a specimen of $350 \mathrm{~cm}$ in total length was caught near the island of Mljet (SOLDO \& DULČIĆ, 2003). To the best of our knowledge, after 1972, no occurrences of this species have been documented in the Adriatic Sea until 2014. Here we report on 8 occurrences of this species from the Adriatic Sea in the period from 2014 to 2017.

\section{MATERIAL AND METHODS}

Records of the shortfin mako sharks presented herein are based on the photographs collected by the editorial board of „Podvodni.hr" (an internet web site oriented toward a community of recreational fishermen from the eastern Adriatic region) and those sent to authors directly by the fishermen. Photographs were accompanied by the date and location of the capture and, in some cases, with data on length and weight. All specimens were captured by commercial and recreational fishermen in the period from 2014 to 2017.

Identification of the specimens was based on photographic material and relied on distinct morphological features described by JARDAS (1996) and KABASAKAL (2015) i.e. spindle shaped moderately slender fusiform body, acutely pointed snout, U-shaped mouth with characteristically protruding lower anterior teeth, being horizontal on jaws; narrow teeth with non-serrated outer edges and without lateral cusps; pointed apex of dorsal fin in adults, slightly rounded in juveniles. Color of the body is dark blue to grey on the upper side of the body and white on the underside. For all specimens, multiple photographs were provided showing important features and special attention was given to features which could potentially allow misidentification with porbeagle Lamna nasus.

For one specimen (number 3, Table 1) total length and weight were provided while length of two specimens (specimens number 1 and 5; Table 1) was approximated from the photographs which showed both the whole body of mako in- dividual and the whole body or part of the body of the fisherman which served as a reference length. This method is approximative and is used only to establish whether individuals are shorter than $195 \mathrm{~cm}$ which is considered as length at first maturity for males. Capture locations are presented further in this paper. In addition, historical Adriatic records of the species prior to 2014 were extracted from SOLDO \& DULČIĆ (2003) and are presented in the Table 1. together with the latest records.

\section{RESULTS AND DISCUSSION}

According to the photographic material examined, in the period from 2014 to 2017,8 individuals of $I$. oxyrinchus were captured in the Adriatic Sea (Table 1; Fig. 1). Out of those, 6 individuals were caught in the eastern Adriatic Sea (Croatian and Montenegrin coast) and 2 in its western part, near the Italian coast (Fig. 2).

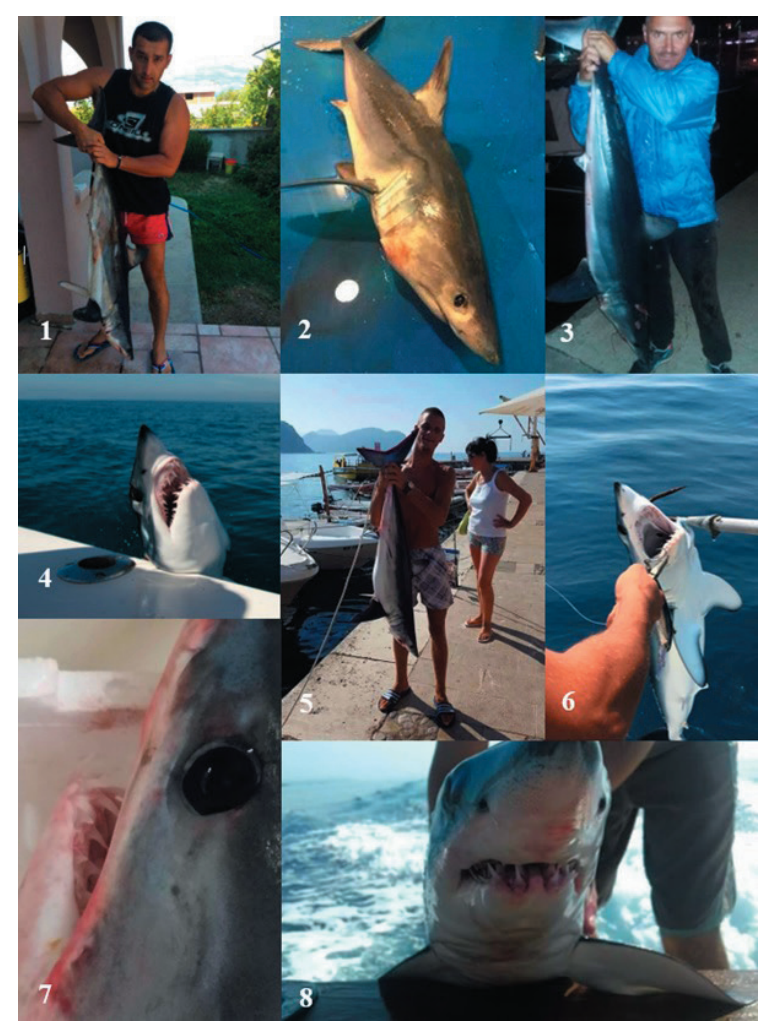

Fig. 1. Photos of individuals of I. oxyrinchus caught in the Adriatic Sea in the period 2014-2017 (numbers on the photos correspond to the specimen numbers in Table 1). 
UDOVIČIĆ et al.: On the recent occurrences of shortfin mako shark, Isurus oxyrinchus (Rafinesque, 1810) ... 239

Table 1. Historical records of I. oxyrinchus in the Adriatic Sea (taken from BRUSINA, 1888 and SOLDO \& DULČIĆ, 2003) with new records from 2014 until today

\begin{tabular}{|c|c|c|}
\hline DATE & LOCATION & $\begin{array}{l}\text { TL cm } \\
\text { (sex, weight) }\end{array}$ \\
\hline $18 \ldots$ & Kvarner Bay & 340 \\
\hline 1871. & Zadar & 95 \\
\hline 27.04.1872. & Izola & 207 \\
\hline 01.05 .1872$. & Mali Lošinj & 120 \\
\hline 06.12 .1872$. & Murter & 300 \\
\hline 30.05 .1876$. & Korčula & 250 \\
\hline 09.06.1876. & Mljet & 100 \\
\hline 05.10 .1876 . & Rab & - \\
\hline 16.08.1877. & Trieste & 200 \\
\hline 10.09.1877. & Krk & 177 \\
\hline 18.04.1878. & Šipan & 235 \\
\hline 10.04.1897. & Brač & 230 \\
\hline 09.06.1879. & Preluka - Rijeka & 180 \\
\hline 22.06.1879. & Rovinj & 150 \\
\hline 27.07.1879. & Volosko - Rijeka & 212 \\
\hline 14.08.1879. & Osor - Cres & 220 \\
\hline 09.09 .1879$. & Makarska & 200 \\
\hline 08.01 .1880$. & Biševo & 260 \\
\hline 15.05.1880. & Umag & 250 \\
\hline 21.07.1881. & Gradac & 190 \\
\hline 15.09.1881. & Malinska - Krk & - \\
\hline 29.04.1882. & Tisno - Murter & 153 \\
\hline 13.05 .1882$. & Novalja - Pag & 400 \\
\hline 23.06.1882. & Preluka - Rijeka & 110 \\
\hline 04.09 .1882$. & Cres & 170 \\
\hline 26.09 .1882$. & Krk & 170 \\
\hline 28.07.1883. & Korčula & 225 \\
\hline 14.08.1883. & Preluka - Rijeka & 189 \\
\hline 02.09 .1884$. & Vis & 130 \\
\hline 29.10 .1884$. & Sali - Dugi Otok & 170 \\
\hline 25.07.1885. & Orebić & 110 \\
\hline 20.08.1886. & Orebić & - \\
\hline 20.11.1886. & Šibenik & 230 \\
\hline 21.06.1886. & Starigrad - Hvar & 120 \\
\hline 29.06.1888. & Volosko - Rijeka & 202 \\
\hline 28.07.1888. & Poreč & 200 \\
\hline 22.07.1890. & Šipan & - (juvenile) \\
\hline $189 \ldots$ & Zadar & - \\
\hline
\end{tabular}

\begin{tabular}{|c|c|c|}
\hline 23.04 .1891$. & Bakar & - (female) \\
\hline 1892. & Cavtat & 100 \\
\hline 07.08 .1892$. & Kvarner & - (female) \\
\hline 29.08 .1895$. & Bojana estuary & 312 \\
\hline 30.09 .1898$. & Bakar & - \\
\hline $19 \ldots$ & Northern Adriatic & - \\
\hline $\begin{array}{l}\text { September } \\
1932 .\end{array}$ & Šolta & $\begin{array}{l}220(W=120 \\
\mathrm{kg})\end{array}$ \\
\hline $\begin{array}{l}\text { January } \\
1934 .\end{array}$ & Brač & 170 (male) \\
\hline 1957. & Trog. Rogoznica & - \\
\hline 1972. & Glavat - Mljet & 350 \\
\hline 11. 08. 2014 & $\begin{array}{l}\text { Bar } \\
\text { (Specimen No. 1) }\end{array}$ & - \\
\hline $\begin{array}{l}\text { December } \\
2015 \text {. }\end{array}$ & $\begin{array}{l}\text { Lošinj } \\
\text { (Specimen No. 2) }\end{array}$ & - \\
\hline 24. 10. 2016. & $\begin{array}{l}\text { Bar } \\
\text { (Specimen No. 3) }\end{array}$ & $\begin{array}{l}150(W=31 \\
\mathrm{kg})\end{array}$ \\
\hline 25.072017. & $\begin{array}{l}\text { Ancona } \\
\text { (Specimen No. 4) }\end{array}$ & - \\
\hline 08.08 .2017$. & $\begin{array}{l}\text { Budva } \\
\text { (Specimen No. 5) }\end{array}$ & Less than 195 \\
\hline 11. 08. 2017. & $\begin{array}{l}\text { Ulcinj } \\
\text { (Specimen No. 6) }\end{array}$ & Less than 195 \\
\hline 19.08 .2017$. & $\begin{array}{l}\text { Tremoli } \\
\text { (Specimen No. 7) }\end{array}$ & - \\
\hline 25.08 .2017$. & $\begin{array}{l}\text { Dubrovnik } \\
\text { (Specimen No. 8) }\end{array}$ & - \\
\hline
\end{tabular}

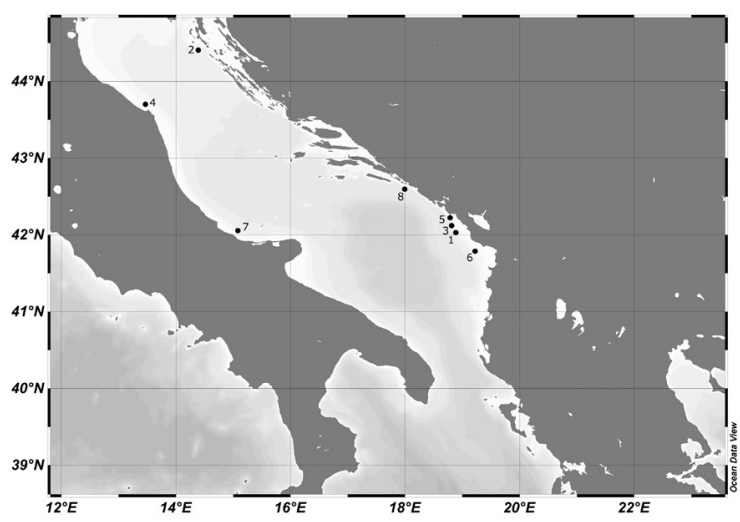

Fig. 2. Locations of occurrences of I. oxyrinchus in the Adriatic sea in the period 2014 - 2017. Numbers correspond to the specimen numbers in Table 1 


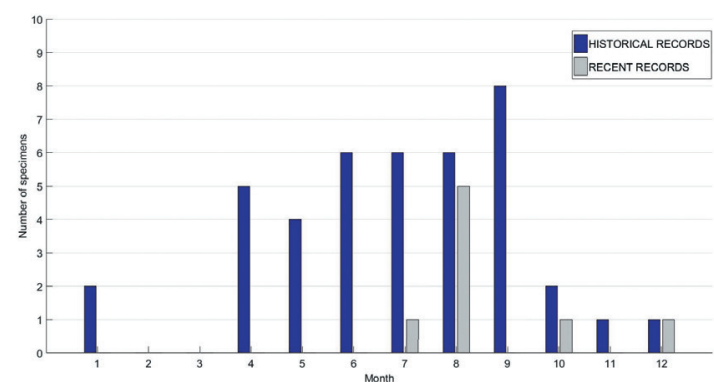

Fig.3. All documented records (historical 1881-1972 and recent 2014-2017) of $\mathrm{I}$. oxyrinchus from the Adriatic Sea presented by number of individuals and month of occurrence

Available data of the caught individuals and estimated lengths are presented in Table 1.

Considering that specimens number 1 and 5 (Fig. 1) were notably shorter than fishermen carrying them, we estimated that mentioned specimens were significantly less than $195 \mathrm{~cm}$ long (TL) indicating sexually immature individuals.

Taking into account the aforementioned length at first maturity for males $(195 \mathrm{~cm})$ and females $(265-280 \mathrm{~cm})$, it could be concluded that at least three specimens were immature individuals. This raises the question whether Adriatic waters could potentially serve as nursery area for I. oxyrinchus. It has been suggested that young shortfin mako sharks tend to have islandoriented movement pattern due to its biological requirements such as feeding (see TUNÇER \& KABASAKAL, 2016 and references therein). Abundance of islands in the eastern Adriatic could therefore provide favorable habitat for early life phases of I. oxyrinchus. It has already been suggested that Adriatic waters serve as a nursery ground for porbeagle Lamna nasus (LIPEJ et al., 2016) on the basis of occurrences of juvenile specimens in the area.

It has been shown that in the area of northwest Atlantic, I. oxyrinchus preys on bluefish, Pomatomus saltatrix, which represents a major food component in its diet (WOOD et al., 2009; HARFORD, 2013). In the recent years, bluefish is an abundant species along eastern Adriatic coast and $I$. oxyrinchus might benefit from their increased presence in the area (DRAGIČEVIĆ et al., 2017). However, it is unknown whether Pomato- mus saltatrix represents significant food component for mako sharks in the Mediterranean.

Before the occurrence of $I$. oxyrinchus in 2014, the last reported specimen from the Adriatic Sea was caught near the island of Mljet in 1972 (SOLDO \& DULČIĆ, 2003). There is a possibility that occurrences in this 42 year long period were either unreported or that deeper research of grey literature, media reports or fishermen and scientists accounts would bring to light more records, however, the possibility of its absence in the area is not without support. Similar pattern of dissapearance in the Adriatic Sea in the period from seventies until 2000's was reported for great white shark Carcharodon carcharias (SOLDO \& DULČIĆ, 2005). FERRETTI et al. (2008), consider I. oxyrinchus as one of the largest elasmobranchs for which largest declines have been observed in the Mediterranean Sea. Same authors estimated a $98.7 \%$ decline in abundance of lamnid sharks over the period of 129 years in the Adriatic Sea. Although relatively rare, occurrences of I. oxyrinchus in the areas in vicinity of the Adriatic Sea have been reported in the recent period. KABASAKAL (2015) reports on the occurrence of 17 individuals ranging from new-borns to huge adult individuals $(65-585 \mathrm{~cm}$ range) from the coast of Turkey (Aegean Sea) in the period from 1950 to 2015. SPERONE et al. (2012) report on the occurrence of 4 specimens in the region of Calabria in Italy (Tyrrhenean and Ionian Sea) in the period from 2000 to 2009. Accounts of two large female shortfin mako sharks $(390 \mathrm{~cm}$ in July of 2003 and $370 \mathrm{~cm}$ in June of 2004) has been reported by CELONA et al. (2004) in the western Ionian Sea.

Out of 8 individuals presented herein, 6 were recorded in the summer period. If we consider all occurrences of this species in the period from 1872 to 2017 in relation to the month of occurrence (Fig. 3), majority of records of $I$. oxyrinchus occurred between April and September. Lower number of records occurred in late Autumn and Winter months. At present, it is difficult to establish whether observed pattern is the result of periodicity of fishing activities or of natural migration patterns of $I$. oxyrinchus. SPERONE et al., (2012) noticed similar pat- 
tern of occurrences of large sharks in the area of Calabria (Southern Italy) and suggested it could be the result of lower number of observers in winter months. On the other hand, pattern observed for I. oxyrinchus might be the result of sharks preference for warmer waters. According to the study by VAUDO et al. (2016), influence of its preffered thermal habitat on its movement could impact the ecology of this species due to rising sea temperatures.

In any case, greater future effort in tracking occurrences of I. oxyrinchus and other large sharks in the Adriatic Sea should be undertaken. Additional effort should also be oriented toward raising the awareness among sportive and professional fishermen about the importance of reporting the catches which often go unreported mainly because of the protection status of I. oxyrichus and other large predatory sharks. Fishermen should be advised to release the individuals whenever possible. Finally, we emphasize the importance of the role of social media and internet discussion groups in tracking of the occurrences of marine species.

\section{ACKNOWLEDGEMENTS}

We are very grateful to Mr. Maro SEKULA, Mr. Mladen ZADRIMA, Mr. Roberto GALANTI and the Editorial Board of www.podvodni.hr for providing the photographs of mako sharks. This work has been supported in part by Croatian Science Foundation under the project LEK-Fish-ResCRO, IP-2016-06-5251.

\section{REFERENCES}

BIANCHI, G., K.E. CARPENTER, J.-P. ROUX, F.J. MOLLOY, D. BOYER \& H.J. BOYER. 1999. FAO species identification guide for fishery purposes. Field guide to the living marine resources of Namibia. FAO, Rome. 265 pp.

BRUSINA, S. 1888. Morski psi Sredozemnoga i Crljenog mora (Sharks of the Adriatic and the Red Sea). Glasnik hrvatskoga naravoslovnoga družtva. III: 167-230, Zagreb. (In Croatian)

CAILliET, G.M., R.D. CAVANAGH, D.W. KULKA, J.D. STEVENS, A. SOLDO, S. CLO, D. MACIAS, J. BAUM, S. KOHIN, A. DUARTE, J.A. HOLTZHAUSEN, E. ANCUÑA, A. AMORIM \& A. DOMINGO. 2009. Isurus oxyrinchus. The IUCN Red List of Threatened Species. 2009. Downloaded on 28 August 2017.

CELONA, A.,L. PISCITELLI \& A. DE MADDALENA. 2004. Two large shortfin makos, Isurus oxyrinchus, Rafinesque, 1809, caught off Sicily, Western Ionian Sea. Annales, Ser. Hist. Nat., 14 (1): 35-42.

CLIFF, G., S.F.J. DUDLEY, \& B. DAVIS. 1990. Sharks caught in the protective gillnets of Natal, South Africa. The shortfin mako shark Isurus oxyrinchus (Rafinesque). South African Journal of Marine Science 9: 115-126.
COMPAGNO, L.J.V., D.A. ELBERT \& M.J. SMALE. 1989. Guide to the sharks and rays of southern Africa. New Holland (Publ.) Ltd., London. $158 \mathrm{p}$.

COMPAGNO, L.J.V. 2002. FAO Species Catalogue. Vol 2: Sharks of the world, Bullhead, mackerel and carpet sharks (Heterodontiformes, Lamniformes and Orectolobiformes). FAO Species Catalogue for Fishery Purposes No. 1, Vol. 2: 1-250.

DRAGIČEVIĆ, B., S. MATIĆ-SKOKO \& J. DULČIĆ. 2017. Fish and Fisheries of The Eastern Adriatic Sea in The Light of Climate Change. Trends in Fisheries and Aquatic Animal Health. Berillis, P. Sharjah UAE: Bentham e-books, 2017. str. 1-22.

FERRETTI, F., R.A. MYERS, F. SERENA \& H.K. LOTZE. 2008. Loss of Large Predatore Sharks from the Mediterranean Sea. Conserv. Biol., 22(4): 952-964.

HARFORD, W.J. 2013. Trophic modeling of shortfin mako (Isurus oxyrinchus) and bluefish (Pomatomus saltatrix) interactions in the western North Atlantic Ocean. Bull. Mar. Sci., 89:161-188.

JARDAS, I. 1996. Jadranska ihtiofauna. Zagreb: Školska knjiga. 533 p. 
KABASAKAL, H. 2015. Occurrence of shortfin makko shark, Isurus oxyrinchus Rafinesque, 1810, off Turkey's coast. Mar. Biodivers. Rec., 8, e134.

LAST, P.R. \& J.D. STEVENS. 1994. Sharks and rays of Australia. CSIRO, Australia. 513 p.

LIPEJ, L., J. UHAN, B. MAVRIĆ \& S. VUJČIĆ-KARLO. 2016. A record of porbeagle, Lamna nasus (Bonnaterre, 1788), in the Gulf of Trieste with discussion on its occurrence in the Adriatic Sea. Acta Adriat., 57 (2): 305-314.

MAIA, A., N. QUEIROZ, J. P. CORREIA \& H. CABAL. 2006. Food habits of the shortfin mako, Isurus oxyrinchus, off the southwest coast of Portugal. Environ. Biol. Fish., 77: 157-167.

PRATT, H.L. \& J.G. CASEY. 1983. Age and growth of the shortfin mako, Isurus oxyrinchus. Prince, E.D. and Pulos, L.M. (eds). Proceedings of the international workshop on age determination of oceanic pelagic fishes: Tunas, billfishes, and sharks NOAA Tech. Rep. NMFS 8: $175-177$.

SOLDO, A. \& J. DULČIĆ. 2003. Stanje psina u istočnom Jadranu. Zbornik 8. Hrvatskog biološkog kongresa sa međunarodnim sudjelovanjem / Višnja Besendorfer, Nevenka Kopjar (ur.). - Zagreb : Hrvatsko Biološko Društvo, 2008, 308-308. (In Croatian)

SOLDO, A. \& J. DULČIĆ. 2005. New record of a great white shark, Carcharodon carcharias (Lamnidae) from the eastern Adriatic Sea. Cybium, 29: 89-90.

SPERONE, E., G. PARISE, A. LEONE, C. MILAZZO V. CIRCOSTA, G. SANTORO, G. PAOLILLO, P. MICARELLI \& S. TRIPEPI. 2012. Spatiotemporal patterns of distribution of large predatory sharks in Calabria (central Mediterranean, southern Italy). Acta Adriat., 53 (1): 13-24.

STEVENS, J.D. 1983. Observations on reproduction in the shortfin mako Isurus oxyrinchus. Copeia 1983(1): 126-130.

TUNÇER, S. \& H. KABASAKAL. 2016. Capture of a juvenile shortfin mako shark, Isurus oxyrinchus Rafinesque, 1810 (Chondrichthyes: Lamnidae) in the Bay of Edremit, northern Aegean Sea (Turkey). Annales, Ser. Hist. Nat, 26, 31-36.

VAUDO, J.J, B. M. WETHERBEE, A.D. WOOD, K. WENG, L.A. HOWEY-JORDAN, G.M. HARVEY \& M.S. SHIVJI. 2016. Vertical movements the shortfin mako sharks (Isurus oxyrinchus) in the western North Atlantic Ocean are strongly influenced by temperature. Mar. Ecol. Prog. Ser. 547, 163-175.

YAMADA, U., S. SHIRAI, T. IRIE, M. TOKIMURA, S. DENG, Y. ZHENG, C. LI, Y.U. KIM \& Y.S. KIM. 1995. Names and illustrations of fishes from the East China Sea and the Yellow Sea. Overseas Fishery Cooperation Foundation, Tokyo, Japan. 288 p.

WEIGMANN, S. 2016. Annotated checklist of the living sharks, batoids and chimaeras (Chondrichthyes) of the world, with a focus on biogeographical diversity. J. Fish Bio., 2016:1201.

WHITE, W.T., P.R. LAST, J.D. STEVENS, G.K. YEARSLEY, FAHMI \& DHARMADI. 2006. Economically important sharks and rays of Indonesia. [Hiu dan pari yang bernilai ekonomis penting di Indonesia]. Australian Centre for International Agricultural Research, Canberra, Australia. 338 pp.

WOOD, A. D., B. M. WETHERBEE, N. E. KOHLER, F. JUANES \& C. WILGA. 2009. Recalculated diet and daily ration of the shortfin mako (Isurus oxyrinchus), with a focus on quantifying predation on bluefish (Pomatomus saltatrix), in the northwest Atlantic Ocean. Fishery Bulletin $107,1-15$. 


\title{
O recentnim nalazima morskog psa kučka, Isurus oxyrinchus (Rafinesque, 1810) u Jadranskom moru
}

\author{
David UDOVIČIĆ, Pero UGARKOVIĆ, Frane MADIRACA i \\ Branko DRAGIČEVIĆ*
}

*Kontakte-pošta: brankod@izor.hr

\begin{abstract}
SAŽETAK
Osam primjeraka morskog psa kučka, Isurus oxyrinchus (Rafinesque, 1810) ulovljeno je u razdoblju od 2014. do 2017. u Jadranskom moru. Primjerci prikazani u ovom radu determinirani su na osnovi fotografskog materijala. Prisutnost nedoraslih i novookoćenih primjeraka ukazuje na važnost istočne obale Jadranskog mora kao područja rastilišta ove vrste. U radu je dat i pregled ranijih nalaza ove vrste u Jadranskom moru.
\end{abstract}

Ključne riječi: Lamnidae, Sredozemno more, morski pas kučak, migratorne vrste 
